\title{
Review: Potensi, Faktor Pembatas dan Pengolahan Rumput Laut Coklat (Phaeophyceae) sebagai Pakan Ayam Petelur
}

\section{Review: Potency, Limiting Factors, and Processing of Brown Seaweed (Phaeophyceae) for Laying Hens Feed}

\author{
Y. L. Dewi ${ }^{1}$, A. Yuniza ${ }^{2}$, Nuraini ${ }^{2}$, K. Sayuti ${ }^{3}$ dan M. E. Mahata ${ }^{2 *}$ \\ ${ }^{1}$ Program Pascasarjana Universitas Andalas \\ ${ }^{2}$ Fakultas Peternakan Universitas Andalas \\ ${ }^{3}$ Fakultas Pertanian Universitas Andalas \\ Kampus Unand Limau Manis, Padang, Indonesia, 25163 \\ *E-mail: mariamahata@gmail.com
}

(Diterima: 11 November 2017; Disetujui: 6 Februari 2018)

\begin{abstract}
ABSTRAK
Tulisan ini dibuat untuk mengetahui potensi, faktor pembatas, dan pengolahan rumput laut coklat (Phaeophyceae) sebagai pakan ayam petelur. Rumput laut coklat (Phaeophyceae) adalah rumput laut yang mengandung pigmen klorofil a, karotin, xanthofil dan fukosantin, pigmen yang dominan adalah fukosantin yang menutupi warna lainnya dan menyebabkan rumput laut ini kelihatan berwarna coklat. Rumput laut coklat memiliki potensi sebagai bahan pakan ayam petelur karena ketersediaan yang melimpah, tidak bersaing dengan kebutuhan manusia, mengandung zat-zat nutrisi, tidak bersifat toksik, kaya asam lemak omega 3, mengandung pigmen fukosantin, alginat dan fukoidan. Faktor pembatas penggunaan rumput laut ini, yaitu 1) Kandungan nutrisi dan kualitas: alginat tinggi, protein rendah, dan energi rendah; 2) Kandungan anti nutrisi: kadar garam tinggi dan phlorotannin; 3) Penanganan dan pengolahan: membutuhkan berbagai pengolahan khusus sebelum digunakan sebagai pakan ternak. Faktor-faktor pembatas tersebut dapat diatasi dengan perlakuan fisik (pencucian, pengeringan, autoklaf, perebusan dan freezing), fermentasi dan penambahan enzim dalam pakan sebagai upaya untuk meningkatkan ketersediaan zat nutrisi dan mendetoksifikasi senyawa antinutrisi. Rumput laut coklat (Phaeophyceae) memiliki potensi sebagai bahan pakan penyusun ransum ayam petelur.
\end{abstract}

Kata kunci: ayam petelur, faktor pembatas, pengolahan, potensi, rumput laut coklat

\section{ABSTRACT}

The paper aimed to describe the potential, limiting factor, and processing of brown seaweed (phaeophyceae) as laying hens feed. Brown seaweed (phaeophyceae) is seaweed containing chlorophyll pigment, carotene, xanthofil and fucoxanthin, the dominant pigment is the fucoxanthin that covers the other colors and causes the seaweed to look brown. Brown seaweed has the potential for laying hens feed because of its abundant availability, does not compete with human needs, contains nutrients, is not toxic, rich in omega 3 fatty acids, contains fucoxanthin pigments, alginate and fucoidan. Limiting the use of this seaweed are 1) Nutrition and quality content: low protein, and low energy; 2) Anti-nutritional factors: high salt and phlorotannin; 3) Handling and processing: requires a variety of special processing before being used as poultry feed. These limiting factors can be solved by physical treatment (washing, drying, autoclaving, boiling and freezing), fermentation and addition of enzymes in the diet in an effort to increase the availability of nutrients and detoxify the anti-nutrition compounds. Brown seaweed (phaeophyceae) has the potential as feed ingredients of laying hens feed.

Keywords: brown seaweed, laying hens, limiting factor, potency, processing 


\section{PENDAHULUAN}

Bahan pakan nonkonvensional merupakan bahan pakan yang tidak atau belum lazim dipakai untuk menyusun ransum. Bahan pakan ini berpotensi sebagai alternatif bahan pakan ternak unggas karena ketersediaannya yang melimpah, tidak bersaing dengan kebutuhan manusia, mengandung zat-zat nutrisi, dan senyawa bioaktif. Bahan pakan ini dapat digunakan sebagai bahan penyusun ransum ternak unggas dan memberikan nilai tambah terhadap kualitas produk yang dihasilkan. Rumput laut merupakan sumber daya laut yang berpotensi untuk dikembangkan sebagai bahan pakan nonkonvensinal ternak unggas. Menurut Rasyid (2004), rumput laut dapat digunakan sebagai bahan campuran pakan ternak, khususnya di negara-negara maritim.

Perairan Indonesia sebagai wilayah tropis memiliki sumberdaya plasma nutfah rumput laut sebesar $6,42 \%$ dari total biodiversitas rumput laut dunia (Santosa, 2003; Surono, 2004) dengan luas wilayah mencapai 1,2 juta hektar yang menjadi habitat rumput laut atau terbesar di dunia (Wawa, 2005 dalam Suparmi dan Achmat, 2009). Rumput laut di perairan Indonesia dapat ditemukan di pantai selatan Jawa Barat dan Banten, di sekitar pantai Santolo, Sayang Heulang di Kabupaten Garut atau di daerah Ujung Kulon Kabupaten Pandeglang. Sementara di daerah pantai barat Sumatera, rumput laut dapat ditemui di pesisir barat Provinsi Lampung sampai pesisir Sumatera Utara dan Nanggroe Aceh Darussalam (Sudaryastuti, 2011).

Rumput laut coklat (Phaephyceae) merupakan salah satu divisi rumput laut yang memiliki jenis yang beraneka ragam. Menurut Winarno (1996), jenis rumput laut coklat yang ada di Indonesia sekitar 134 jenis. Sargassum sp, Turbinaria $s p$, dan Padina $s p$. (Phaeophyta) merupakan jenis rumput laut coklat yang banyak ditemukan dan cukup melimpah di perairan Indonesia (Rachmaniar, 2005).

Penelitian terdahulu diketahui bahwa senyawa yang terkandung pada rumput laut coklat seperti alginat dan fukoidan dapat menurunkan kolesterol pada kuning telur (Carillo et al., 2012), serta fukosantin dapat menurunkan kolesterol dan meningkatkan warna kuning pada kuning telur (Al-Harthi dan El-Deek, 2012). Selain itu, pemberian rumput laut coklat pada ayam petelur berpengaruh terhadap peningkatan omega 3 pada telur (Carrillo et al., 2008), dan berpengaruh positif terhadap performa ayam petelur (Horhoruw et al., 2009). Rumput laut sebagai pakan ternak sering digunakan sebagai sumber mineral dan vitamin, di Jepang pemberian rumput laut (Porphyraa tropurpurae) pada unggas dengan level $2.5 \%$ - 10\% dari total pakan memberikan hasil yang baik, meningkatkan kesehatan, bobot telur, produksi telur, kekuatan kulit telur, dan daya tetas (Horhoruw et al., 2009).

Mahata et al. (2015) melaporkan pemberian beberapa jenis rumput laut coklat (Padina australis, Sargassum binderi, Sargassum crassifolium, Turbinaria decurrens dan Turbinaria murayana) yang tidak diolah dalamransum broilersampai $10 \%$ berpengaruh negatif terhadap performa broiler, namun berpengaruh baik terhadap kualitas karkas, penurunan kolesterol daging paha, dan lemak daging paha. Dijelaskannya pengaruh negatif tersebut diduga oleh kandungan garam rumput laut yang tinggi. Penelitian oleh Carillo et al. (2012), penambahan rumput laut Sargassum sp sebanyak 4, 6, dan $8 \%$ dalam ransum ayam petelur tanpa pengolahan berpengaruh terhadap penurunan produksi telur tetapi tidak berpengaruh tehadap berat telur dan konversi pakan serta berpengaruh positif terhadap penurunan kolesterol kuning telur.

Pemanfaatan rumput laut coklat sebagai bahan pakan penyusun ransum untuk ayam petelur perlu dilakukan secara intensif, namun rumput laut ini memiliki keterbatasan dalam penggunaanya yaitu polifenol (Morand et al., 1991), garam (Ghosh et al., 1999; Moen et al., 1999), dan karbohidrat (Jacob, 2015). Hasil penelitian lain melaporkan, pemberian rumput laut pada unggas sebesar $5-10 \%$ masih aman tetapi pemberian rumput 
laut dengan konsentrasi yang tinggi dan dalam waktu yang lama akan berpengaruh negatif (El-Deek et al., 1985). Jacob (2015) menjelaskan bahwa tepung rumput laut dapat ditambahkan ke dalam pakan unggas sebesar $5-15 \%$, tergantung pada spesies rumput laut, jenis dan usia ternak, karena sebagian besar protein dan karbohidrat rumput laut tidak dapat dicerna oleh ternak non ruminansia. Untuk mengatasi faktor-faktor pembatas tersebut perlu dilakukan pengolahan untuk meningkatkan ketersediaan zat nutrisi, menurunkan faktor-faktor pembatas pada rumput laut coklat sehingga penggunaannya dalam ransum ayam petelur optimal. Tujuan dari penulisan ini adalah untuk mengetahui potensi, faktor pembatas penggunaan rumput laut coklat dan metode pengolahannya untuk mengatasi faktor pembatas tersebut sebagai pakan ayam petelur.

\section{Pentingnya Rumput Laut Coklat (Phaeophyceae) sebagai Pakan Ayam Petelur}

Rumput laut coklat adalah salah satu sumber daya laut yang memenuhi seluruh kriteria dari suatu bahan pakan. Produksi rumput laut melimpah tetapi masih banyak yang belum dimanfaatkan secara optimal di Indonesia terutama rumput laut coklat (Phaeophyceae). Sebagaimana Kementerian Kelautan dan Perikanan (2011) melaporkan produksi rumput laut Indonesia mencapai 4.305.027 ton/tahun. Luas indikatif dan efektif potensial untuk komoditas rumput laut di Indonesia, yaitu 769.452 ha dan 384.733 ha berturut-turut (Direktorat Jenderal Perikanan Budidaya, 2013). Hal yang mengisyaratkan rumput laut dapat digunakan sebagai bahan pakan disebutkan oleh Rimber (2007) bahwa rumput laut adalah suatu yang sangat penting untuk dipertimbangkan sebagai suplemen makanan pada abad 21 ini sebagai sumber protein, lemak, polisakarida, mineral, vitamin dan enzim. Becker (2004) menyatakan bahwa 30\% rumput laut yang diproduksi di dunia dijual untuk digunakan sebagai pakan ternak. Rumput laut digunakan sebagai bahan campuran pakan ternak, khususnya di negara-negara maritim (Rasyid, 2004), karena rumput laut mengandung zat-zat nutrisi yang baik untuk ternak. Disebutkan juga oleh Naidu et al. (1993), pemberian pakan rumput laut dalam jangka waktu yang lama tidak menyebabkan pengaruh negatif terhadap hewan percobaan, oleh karena itu rumput laut aman untuk dikonsumsi oleh manusia dan hewan.

Rumput laut, baik sebagai sumber lemak dan vitamin larut air maupun pigmen seperti klorofil (David, 2001; Becker 2004). Mohd et al. (2000) menyatakan bahwa $G$. changii mengandung komposisi asam lemak tak jenuh yang tinggi sebesar $74 \%$, terutama asam lemak omega 3 dan $26 \%$ asam lemak jenuh (terutama asam lemak palmitat), selain itu juga memiliki kalsium dan zat besi yang cukup tinggi.

Rumput laut dilaporkan mengandung senyawa bioaktif, seperti alginat (Mahata et al., 2015), fukoidan (Song et al., 2012; Synytsya et al., 2010), fukosantin (Haugan et al., 1995; Matsuno, 2001), dan asam lemak tak jenuh (PUFA/Poly-Unsaturated Fatty Acid) (Carrillo et al., 2012; Ismail, 2016). Senyawa bioaktif ini memiliki aktivitas hipokolesterolemik, antiviral, antibiotik, anti-inflamatori, anti-trombin, antikoagulasi, antilipemik, inhibitor enzim, dan stimulan (Pal et al., 2014).

Penelitian oleh Carillo et al. (2012) diketahui bahwa penggunaan rumput laut Sargassum spp. dalam ransum ayam petelur dapat menurunkan kolesterol kuning telur. Lebih lanjut disebutkan olehnya bahwa faktor-faktor yang mempengaruhi penurunan kolesterol ini diantaranya dipengaruhi oleh polisakarida dan asam lemak tak jenuh rantai panjang (PUFA/Poly-Unsaturated Fatty Acid).

Polisakarida rumput laut diantaranya alginat, fukoidan, mannitol, dan laminarin (Yuan, 2008; Casas, 2009). Senyawa-senyawa ini mempunyai pengaruh hiperkolesterolemik yang menyebabkan terbentuknya formasi sistem viskositas di dalam usus halus 
yang menyebabkan penurunan kecepatan penyerapan nutrisi seperti glukosa dan lemak di dalam darah, lalu membentuk suatu koloid berion, selanjutnya dikeluarkan bersama feses (Kiriyama et al., 1968; Lamela et al., 1989; Panlasigui et al., 2003).

Mouritsen (2009) mengatakan rumput laut kaya akan karbohidrat jenis polisakarida yang tidak dapat dicerna, meskipun begitu karbohidrat ini baik untuk kesehatan tubuh. Koivikko (2008) menjelaskan bahwa rumput laut merupakan sumber serat yang baik karena kandungan seratnya yang tinggi terutama serat larut yang mencapai $40 \%$ dalam berat kering. Alginat sebagai serat larut mempunyai berbagai manfaat untuk kesehatan yaitu menurunkan level kolesterol darah, glukosa darah, menurunkan tingkat toksisitas koloni mikroba lumen usus yang tidak menguntungkan, menyerap racun pada kolon, dan merubah mikroflora usus (Brownlee et al., 2005). Selain itu, disebutkan olehnya manfaat tambahan dari senyawa ini yaitu membantu penyembuhan luka dan meningkatkan daya tahan tubuh. Begitu juga dengan fukoidan yang mempunyai aktivitas biologis mencangkup anthelmintic, antibateri, anti koagulasi, anti fungi, anti inflammatory, anti malaria, dan anti viral (Wang et al., 2011).

Beberapa penelitian telah membuktikan bahwa rumput laut yang mengandung komponen agar, karagenan dan alginat mempunyai pengaruh yang kuat dalam menurunkan kolesterol serum (Suzuki et al., 1993; Ren et al., 1994; Widiastuti, 2001; Astawan, 2005) dan meningkatkan kadar HDL (Ren et al., 1994; Wong et al., 1999). Hasil penelitian Wikanta et al. (2002) dan Wikanta et al. (2003), menunjukkan bahwa pemberian senyawa alginat $(1 \mathrm{~g} / \mathrm{kg} \quad \mathrm{BB})$ menunjukkan penurunan kadar glukosa darah maupun kolesterol pada hewan percobaan. Mahata et al. (2015) melaporkan bahwa rumput laut coklat mengandung alginat yang berbeda-beda, Padina australis mengandung $22.81 \%$ alginat, Turbinaria decurrens $7.7 \%$, Turbinaria murayana $8.03 \%$, Sargassum crassifolium $8.65 \%$ dan Sargassum binderi
$11.51 \%$, dan pemberian rumput laut coklat (Padina australis, Turbinaria decurrens, Sargassum binderi dan Sargassum crassifolium) sebanyak $10 \%$ dari ransum berpengaruh terhadap penurunan kolesterol daging paha, penurunan lemak paha dan tidak perpengaruh terhadap lemak hati.

Asam lemak rumput laut tidak hanya memodifikasi komposisi asam lemak pada telur ayam petelur, tetapi juga dapat berkontribusi dalam penurunan level kolesterol (Carillo et al., 2012). Carillo et al. (2012) mengatakan banyak hipotesis mengenai mekanisme penurunan kolesterol oleh asam lemak terutama asam lemak n-3. Welch and Borlak (2008) menjelaskan, asam lemak ini merangsang pembentukan HDL (High Density Lipoprotein), yang bertanggung jawab mengangkut kolesterol dari jaringan dan organ menuju hati untuk di metabolisme, sehingga terjadi penurunan penyerapan kolesterol, peningkatan ekskresi kolesterol dan garam-garam empedu, penurunan sintesis kolesterol, dan peningkatan aktivitas enzim yang mengkatalitis dalam reaksi antara lesitin dan kolesterol untuk memproduksi lysolesitin dan ester kolesterol.

Penggunaan rumput laut Macrocystis pyrifera $10 \%$ dalam ransum, efektif meningkatkan n-3 FA (Carrillo et al., 2008). Schiavone et al. (2007) menjelaskan bahwa rumput laut dapat digunakan sebagai alternatif sumber minyak ikan yang mengandung n-3 FA dalam ransum broiler.

Haugan et al. (1995) dan Matsuno (2001) berpendapat bahwa fukosantin merupakan karotenoid utama yang terdapat dalam rumput laut coklat. Wehr (2003) mengatakan bahwa warna coklat pada rumput laut ini berasal dari fukosantin.

Fukosantin merupakan feed additive yang sangat baik untuk meningkatkan warna kuning pada kuning telur (Strand et al., 1998). Berdasarkan hasil penelitian Al-Harthi dan El-Deek (2012) dapat diketahui bahwa penambahan $6 \%$ rumput laut coklat dalam ransum ayam petelur, signifikan menurunkan 
kolesterol plasma, kuning telur, dan trigliserida, selain itu juga terjadi peningkatan total karoten dan lutein ditambah zeasantin pada telur. Hasil penelitian lainnya oleh Starnd et al. (1998), suplementasi rumput laut Fucus serratus dan Fucus vesiculosus sebesar 15\% menghasilkan karoten kuning telur 12-15 kali lebih tinggi dibandingkan dengan kontrol. Penggunaan rumput laut Macrocystis pyrifera $10 \%$ dalam ransum, efektif meningkatkan warna kuning telur (Carrillo et al., 2008).

Pigmen utama rumput laut Fucus serratus adalah fukosantin yang tidak terdeteksi pada kuninng telur (Jensen, 1963; Jensen, 1966), tetapi produk hidrolisis fukosantin adalah fukosantinol, paracentrone, dan fucoxanthinol 3 sulfat yang terdeteksi pada kuning telur (Strand et al., 1998). Hidrolisis fucoxanthin, sebagai suatu asetat alami yang sesuai dengan fenomena umum, dimana ikan dan burung menyerap xanthophyll (oksigen yang mengandung karotenoid), kemudian ester asam lemak karotenol terhidrolisis di usus halus hewan dan diserap sebagai karoten bebas di lumen usus dan pada telur burung, karotenoid biasanya hadir sebagai karotenoid bebas (Schiedt, 1985). Pada ayam, ester xanthophyll yang dicerna terhidrolisis dalam lumen usus dan diangkut melalui darah dalam bentuk bebas (Tyczkowski and Hamilton, 1986a; Tyczkowski and Hamilton, 1986b). Setelah diserap dan melewati mukosa usus, karotenoid diangkut dalam lipoprotein plasma (Schiedt, 1985). Setelah diserap, karoten masuk dan diangkut dalam sirkulasi darah, untuk selanjutnya disimpan dalam jumlah besar di dalam kulit, bulu, jaringan lemak, dan kuning telur (CP-Bulletin, 2007). Lebih lanjut dijelaskan, xanthophyll disimpan tubuh dalam otot dan kulit, yang selanjutnya disalurkan ke ovarium pada awal masak kelamin, proses penyaluran xanthophyll berlangsung selama fase produksi telur.

Pengaruh fukosantin terhadap metabolisme lipid yaitu fukosantin signifikan menurunkan kosentrasi trigliserida plasma dan hati serta transport kolesterol di hati melalui penurunan regulasi reseptor LDL
(Low Density Lipoprotein) dan reseptor Scavenger class B member 1 (SR-B1) (Gammoned dan D'Orazio, 2015). Lebih lanjut dijelaskan, suplementasi fukosantin juga dapat menurunkan ekspresi mRNA dari enzim fatty acid synthase (FAS), yang mengkatalisis sintesis asam lemak. Selain itu, senyawa ini juga dapat menghambat transport glukosa pada sel adiposit melalui penurunan posporilasi substrat reseptor insulin 1 (insulin receptor substrate 1, IRS-1). Kemudian dijelaskan olehnya bahwa fukosantin signifikan menurunkan konsentrasi trigliserida plasma dan hati serta positif berpengaruh terhadap aktifitas enzim regulasi kolesterol seperti 3-hydroxy-3-methylglutaryl-CoA reductase dan acyl-CoA serta mempengaruhi ekspresi gen yang berasosiasi dengan metabolisme lipid.

Selain mempengaruhi warna kuning telur dan kolesterol, fukosantin juga menarik perhatian para peneliti karena bioaktivitasnya yang sangat baik seperti antioksidan (Nomura et al., 1997), antikanker (Yoshiko dan Hoyuku, 2007), anti sinar ultra violet (Urikura et al., 2011), dan lain-lain. Fukosantin dari alga coklat berpotensi untuk dikembangkan sebagai bahan nutraseutikal terutama sebagai antioksidan dan agen kemopreventif karena kemampuannya dalam meredam radikal bebas (Nursid et al., 2013).

Rumput laut, selain dapat meningkatkan kualitas produk telur, tetapi juga dapat mempertahankan performa ayam petelur. Sebagaimana hasil penelitian yang diperoleh oleh Horhoruw et al. (2009), pemberian rumput laut coklat Porphyraatropurpurae dalam ransum ayam dengan level 2.5\%$10 \%$ dari total pakan dapat meningkatkan kesehatan, bobot telur, produksi telur, kekuatan kulit telur dan daya tetas. Penggunaan rumput laut Macrocystis pyrifera $10 \%$ dalam ransum, efektif meningkatkan ketinggian albumen, tetapi tidak untuk berat telur (Carrillo et al., 2008).

Pengaruh baik pada ternak yang diberikan oleh rumput laut ini dipengaruhi oleh senyawa-senyawa yang terkandung 
Vol. 20 (2): 53-69

Tabel 1. Senyawa-Senyawa Rumput Laut

\begin{tabular}{|c|c|c|}
\hline Senyawa & Fungsi & Sumber \\
\hline \multirow[t]{4}{*}{ Alginat } & $\begin{array}{l}\text { Menurunkan kolesterol dan lemak daging } \\
\text { paha broiler. }\end{array}$ & (Mahata et al., 2015) \\
\hline & Menurunkan kolesterol serum daram. & $\begin{array}{l}\text { (Suzuki et al., 1993; Ren et } \\
\text { al., 1994; Widiastuti, 2001; } \\
\text { Astawan, 2005) }\end{array}$ \\
\hline & Meningkatkan HDL. & $\begin{array}{l}\text { (Ren et al., } 1994 \text { Wong et } \\
\text { al., 1999) }\end{array}$ \\
\hline & Menurunkan kolesterol dan kadar glukosa. & $\begin{array}{l}\text { Wikanta et al. (2002 dan } \\
\text { 2003) }\end{array}$ \\
\hline \multirow[t]{2}{*}{ Fukoidan } & $\begin{array}{l}\text { Aktivitas biologis mencangkup anthelmintic, } \\
\text { anti bateri, anti koagulasi, anti fungi, anti } \\
\text { inflammatory, anti malaria dan anti viral. }\end{array}$ & (Wang et al., 2011) \\
\hline & Menurunkan kolesterol. & $\begin{array}{l}\text { (Yuan, } 2008 \text { dan Casas, } \\
\text { 2009) }\end{array}$ \\
\hline \multirow[t]{3}{*}{ Fukosantin } & $\begin{array}{l}\text { Penurunan signifikan kolesterol plasma, } \\
\text { kuning telur dan trigliserida. }\end{array}$ & $\begin{array}{l}\text { Al-Harthi dan El-Deek } \\
\text { (2012), } \\
\text { (Okuzumi et al 1993; }\end{array}$ \\
\hline & Antioksidan. & $\begin{array}{l}\text { Nomura et al., 1997; Yan et } \\
\text { al 1999; Nursid et al., 2013) }\end{array}$ \\
\hline & Antikanker. & (Yoshiko dan Hoyoko, 2007) \\
\hline \multirow[t]{3}{*}{ Omega 3} & $\begin{array}{l}\text { Menurunkan kolesterol dan meningkatkan } \\
\text { kadar HDL dalam darah }\end{array}$ & (Welch dan Borlak, 2008) \\
\hline & $\begin{array}{l}\text { Memodifikasi komposisi asam lemak pada } \\
\text { telur }\end{array}$ & (Welch dan Borlak, 2008) \\
\hline & $\begin{array}{l}\text { Dapat menurunkan resiko penyakit jantung, } \\
\text { trombosis, dan ateroklerosis }\end{array}$ & (Mishra et al., 1993) \\
\hline \multicolumn{2}{|c|}{ Vitamin A, B1, B12, C, thiamine, dan riboflavin yang tinggi } & (Jacob, J. 2014) \\
\hline \multicolumn{2}{|c|}{$\begin{array}{l}\text { Mineral sodium, calcium, magnesium, potassium, chlorine, } \\
\text { sulfur and phosphorus and the microminerals iodine, iron, } \\
\text { zinc, copper, selenium, molybdenum, fluoride, manganese, } \\
\text { boron, nickel and cobalt }\end{array}$} & $\begin{array}{l}\text { (Burtin, 2003; Madhusudan } \\
\text { et al., 2011) }\end{array}$ \\
\hline
\end{tabular}

dalam rumput laut, seperti alginat, fukoidan, fukosantin, omega 3, vitamin dan mineral. Sebagaimana dijabarkan pada Tabel 1 dan Tabel 2.

\section{Faktor Pembatas Penggunaan rumput Laut Coklat}

Rumput laut coklat mengandung senyawa-senyawa seperti alginat, fukosantin, fukoidan, vitamin dan mineral yang sangat bermanfaat dan dibutuhkan oleh ternak untuk meningkatkan kesehatan ternak dan meningkatkan kualitas produk ternak yang dihasilkan. Tetapi penggunaan rumput laut dalam ransum unggas berpengaruh terhadap penurunan performa ternak, sebagaimana penelitian yang dilakukan oleh Ventura et al. (1994), bahwa penggunaan rumput laut Ulva rigida $20 \%$ dan $30 \%$ menurunkan AME (Apperent Metabolism Energy), pertambahan bobot badan, dan peningkatan konversi pakan; Zahid et al. (1995), penambahan $20 \%$ dan 30\% rumput laut menyebabkan penurunan bobot tubuh, hal ini disebabkan oleh garam yang terkandung dalam rumput laut yang menyebabkan ternak terserang diare; Zaid et al. (2001), pemberian 20\%, $30 \%$, dan $40 \%$ menunjukkan penurunan petumbuhan pada ternak; Al-Harthi dan El-Deek (2011), penggunaan 6\% rumput 
Tabel 2. Alginat Rumput Laut Coklat (\%)

\begin{tabular}{lc}
\hline Spesies Rumput Laut & Alginat \\
\hline Padina australis & 22,81 \\
Turbinaria decurrens & 7,70 \\
Turbinaria murayana & 8,03 \\
Sargassum crassifolium & 8,65 \\
Sargassum binderi & 11,51 \\
\hline
\end{tabular}

Sumber : Maria et al. (2015)

Tabel 3. Faktor-Faktor Pembatas Rumput Laut sebagai Pakan Unggas

\begin{tabular}{|c|c|c|}
\hline Faktor Pembatas & Kriteria & Sumber \\
\hline \multirow{4}{*}{$\begin{array}{l}\text { Kandungan dan } \\
\text { Kualitas Nutrisi }\end{array}$} & $\begin{array}{l}\text { Protein tidak dapat } \\
\text { dimanfaatkan }\end{array}$ & (Burtin. 2003; Jacob, 2015) \\
\hline & Energi rendah & (Norziah and Ching, 2000) \\
\hline & Serat kasar tinggi & (Mahata et al., 2015) \\
\hline & $\begin{array}{l}\text { Karbohidrat tidak dapat } \\
\text { dicerna }\end{array}$ & $\begin{array}{l}\text { (Boyen et al., 1990; Brown, Presti, } \\
\text { 1991; Larsen et al., 1993; Horn, } \\
\text { 2000; Jacob, 2015) }\end{array}$ \\
\hline \multirow[t]{2}{*}{$\begin{array}{l}\text { Kandungan Anti } \\
\text { Nutrisi }\end{array}$} & Garam & $\begin{array}{l}\text { (Zahid et al., 1993, Ghosh et al., } \\
\text { 1999; Moen et al., 1999; Mahatta et } \\
\text { al., 2015) }\end{array}$ \\
\hline & Phlorotannin & $\begin{array}{l}\text { (Morand et al. 1991; Wang et al., } \\
\text { 2011) }\end{array}$ \\
\hline $\begin{array}{l}\text { Penanganan dan } \\
\text { Pengolahan }\end{array}$ & $\begin{array}{l}\text { Rumput laut tidak dicuci } \\
\text { dengan air tawar }\end{array}$ & (Mahatta et al., 2015) \\
\hline
\end{tabular}

laut dalam ransum berpengaruh terhadap penurunan performa ayam petelur (hen day production, berat telur, massa telur, konsumsi, konversi pakan dan bobot badan ternak); Carrilo et al. (2012), penambahan 4, 6, dan $8 \%$ rumput laut secara tidak signifikan mempengaruhi peningkatan konsumsi dan signifikan menurunkan produksi telur; Armin et al. (2014), suplementasi Sargassum sp $5 \%$ dan $10 \%$ menurunkan berat badan dan konsumsi ternak. Selain menyebabkan penurunan perforna ternak, pemberian rumput laut menyebabkan mortalitas, sebagaimana yang dialami oleh Zahid et al. (1995), terjadi mortalitas pada perlakuan rumput laut hingga $10.2 \%$. Hal yang sama juga dialami kembali oleh Zaid et al. (2001), mortalitas ternak selama penelitian $13.8 \%$. Berdasarkan penelitian ini tapat diketahui bahwa pemberian rumput laut dalam ransum unggas lebih dari $10 \%$ berpengaruh negatif terhadap performa dan dapat menimbulkan mortalitas sehingga penggunaannya sebagai bahan pakan unggas terbatas.

Alginat yang terkandung pada rumput laut coklat pada Tabel 1. tergolong tinggi. Alginat yang tinggi ini dapat mempengaruhi kecernaan zat-zat makanan dan jika dalam konsentrasi tertentu yang tepat dalam ransum unggas, alginat akan berpengaruh baik terhadap ternak. Pada rumput laut coklat, alginat adalah komponen struktural utama (Kloareg dan Quatrano, 1988). Alginat pada rumput laut tidak dapat dimanfaatkan sebagai sumber energi bagi ternak non rumunansia karena senyawa ini tidak dapat didegradasi oleh enzim pencernaan non ruminansia. Sesuai dengan pendapat Horn (2000), bahwa hidrolisis alginat diperkirakan pada umumnya tidak ditemukan. Sumber-sumber yang dapat melisis atau memecah alginat, yaitu microorganisme, moluska laut dan 
echinoderm (Boyen et al., 1990; Brown and Preston, 1991; Larsen et al., 1993). Jacob (2014), menyebutkan sebagian besar protein dan karbohidrat pada rumput laut tidak dapat dicerna oleh non ruminant.

Faktor-faktor pembatas lainnya yang terdapat dalam rumput laut, yaitu polifenol (Morand et al., 1991) dan garam (Ghosh et al., 1999; Moen et al., 1999; Mahata et al., 2015). Polifenol (Morand et al., 1991) dan garam (Ghosh et al., 1999; Moen et al., 1999), pada rumput laut dapat menurunkan biodegradabilitas. Phlorotannin merupakan senyawa polyphenolic yang hanya terdapat pada rumput coklat dan memiliki aktivitas antimikroba yang sangat kuat (Chojnacka et al., 2012). Phlorotannin masuk dalam kelompok tannin (Koivikko, 2008). Wang et al. (2011), yang menyatakan phlorotannin membentuk senyawa kompleks dengan protein dan menurunkan deaminasi asam amino, diikuti penurunan konsentrasi $\mathrm{NH}_{3}$ dengan peningkatan konsentrasi phlorotannin (Tabel 3).

Kandungan garam pada rumput laut yang tidak diolah tinggi, sebagaimana penelitian yang dilakukan oleh Mahata et al. (2015), kandungan garam rumput laut tanpa olah: Padina australis 10.07\%, Turbinaria decurrens $11.20 \%$, Turbinaria murayana sebesar 13,08\%, Sargassum crassifolium 11,21\%, dan Sargassum binderi 12,24\%. Sedangkan kandungan garam $(\mathrm{NaCl})$ dalam ransum unggas terbatas $0.25 \%-0.5 \% /$ $\mathrm{kg}$ ransum (Berger, 2006). Oleh sebab itu sebagian besar peneliti mencuci rumput laut yang akan digunakan untuk menurunkan kadar garam. Tetapi rumput laut yang dicuci dengan air tawar belum mampu menurunkan kadar garam dengan baik, hal ini telah dibuktikan dengan penelitian bahwa kadar garam rumput laut Sargassum binderi dan Sargassum crassifolium tanpa olah berturutturut $17.23 \%$ dan $17.01 \%$ dan dicuci $14.89 \%$ dan $11.97 \%$ (Laboratorium Nutrisi Non Ruminansia Fakultas Peternakan Universitas andalas, 2016).

$$
\text { Pada penelitian Mahata et al }
$$

(2015), rumput laut yang tinggi kadar garam ditambahkan ke dalam ransum ayam broiler percobaan sehingga menyebabkan ternak mencret, pertumbuhan yang terhambat dan tingkat mortalitas yang tinggi. Di dalam rongga perut ternak terdapat lendir yang melampisi jantung dan hati, hati mengalami kelainan dan pembengkakan pada ginjal. Efek negatif ini salah satunya disebabkan oleh kadar garam yang tinggi dalam ransum. Kejadian dalam penelitian ini sesuai dengan keterangan dari Charoen Pokphand (2005) bahwa ketika kadar garam ditingkatkan, broiler akan menambah konsumsi air untuk membantu dan menetralisir garam. Hal ini akan mengakibatkan broiler membuang sebagian besar kelebihan air melalui feses. Akibatnya feses menjadi becek dan lembek.

Kadar garam dalam ransum unggas melebihi batas maksimal akan berdampak negatif terhadap ternak, diantaranya ayam akan terserang penyakit asites. Menurut Tri (1993) penyebab asites belum diketahui secara pasti, namun penggunaan garam yang berlebihan di dalam pakan diperkirakan dapat menimbulkan penyakit ini. Asites (water belly)/busung pada ayam merupakan suatu timbunan cairan yang tergolong transudat (tidak berhubungan dengan proses radang) di dalam rongga perut (Tabbu, 2002). Sebelumnya Julian (1993) mengatakan bahwa, asites merupakan gangguan metabolisme yang berhubungan dengan ketidakmampuan tubuh untuk menyediakan oksigen yang cukup akibat kebutuhan oksigen yang meningkat. Pada ayam pedaging yang sedang tumbuh, asites sering menyebabkan kematian akibat kegagalan jantung (ventrikel kanan) dan umumnya disebabkan oleh sindrom hipertensi pulmonum (pulmonary hypertension syndrome/PHS) (Calnek et al., 1997). Zahid et al. (1995), menyebutkan mortalitas yang terjadi pada penelitiannya disebabkan oleh disebabkan oleh garam yang terkandung dalam rumput laut yang menyebabkan ternak terserang diare.

\section{Pengolahan Rumput Laut Coklat}

Pengoptimalan penggunaan rumput

Potensi, Faktor Pembatas, dan ... (Dewi et al.) 
laut sebagai pakan unggas membutuhkan pengolahan seperti pencucian, pemanasan, penambahan enzim, dan fermentasi untuk mengatasi faktor-faktor pembatas pada rumput laut diantaranya polifenol (Morand et al., 1991), garam (Ghosh et al., 1999; Moen et al., 1999), karbohidrat (Jacob, 2015), dan meningkatkan kecernaan nutrisi rumput laut.

Pada beberapa penelitian, rumput laut yang digunakan dalam penelitian dicuci dengan air tawar terlebih dahulu untuk menanggalkan sisa-sisa pasir, karang-karang kecil dan garam yang menempel pada rumput laut tersebut (Zahid et al., 1993; Ventura et al., 1994; Ginzberg et al., 2000; Zahid et al., 2011; Wisnu dan Rachmawati, 2005; Kumar dan Kaladharan, 2007; El-Deek dan Brikaa, 2009a; El-Deek dan Brikaa, 2009b; Ozaki et al., 2013). Selain itu, ada suatu penelitian oleh Naidu et al. (1993), rumput laut yang digunakan dalam penelitian dibersikan dengan air laut untuk tujuan yang sama.

Proses pencucian dengan air tawar dapat menanggalkan sisa-sisa pasir laut, karang-karang kecil, garam yang menempel pada rumput laut dan dapat mengurangi bau spesifik dari rumput laut. Hal ini sesuai dengan Wisnu dan Rachmawati (2005), proses pengeringan rumput laut basah yang terlebih dahulu dicuci dengan menggunakan air tawar hingga bau spesifik rumput laut berkurang. Disebutkan oleh peneliti bahwa air tawar menyebabkan kandungan garam dan kotoran yang menyelimuti rumput laut menjadi hilang. Selanjutnya dijelaskan bahwa air tawar mengikat cairan yang terkandung dalam air laut sehingga selama proses penjemuran kadar air dalam rumput laut cepat berkurang. Lebih lanjut dijelaskan, air tawar juga berfungsi sebagai pelapis yang melindungi rumput laut dalam proses pengeringan berikutnya sehingga rumput laut basah tersebut menjadi kering tanpa kehilangan nilai nutrisi penting dari dalam tubuhnya. Oleh karena kandungan nutrisi penting dalam rumput laut kering tawar paling tinggi sehingga nilai energi yang terkandung di dalamnya juga tinggi. Rumput laut kering tawar ini merupakan hasil olahan rumput laut yang paling sesuai untuk dikonsumsi sebagai bahan makanan (Wisnu dan Rachmawati, 2005).

Menurut Lisnley et al. (1996), air merupakan pelarut yang efektif. Lebih lanjut dijelaskan bahwa polaritas muatan pada molekul air mempermudah terjadinya gangguan pada kristal-kristal ionik melalui pengurangan gaya tarik antarion. Disebutkan juga bahwa salah satu senyawa yang mudah larut dalam air adalah garam.

Upaya mengatasi permasalahan garam yang belum dapat teratasi dengan metode pencucian dengan air tawar. Oleh sebab itu dilakukanlah penelitian berupa perendaman rumput laut, diperoleh kandungan garam rumput laut Sargassum binderi dan Sargassum crassifolium perendaman 1 hari, yaitu $1.36 \%$. Dari hasil penelitian ini dapat diketahui bahwa dengan perendaman 1 hari dapat menurunkan garam secara drastis (Laboratorium Nutrisi Non Ruminansia Fakultas Peternakan Universitas andalas, 2016).

Pengolahan-pengolahan rumput laut yang telah dilakukan oleh peneliti sebelumnya untuk mengatasi faktor-faktor pembatasnya, yaitu autoklaf, perebusan (Attia et al., 1998; El-Deek dan Al-Harthi, 2009; El-Deek dan Brikaa, 2009; Al-Harthi dan El-Deek, 2011; El-Deek et al., 2011; Al-Harthi dan El-Deek, 2012a), penambahan enzim (Attia and Abd El-Rahman, 2001; Attia et al., 2003; 2008; ElDeek dan Al-Harthi, 2009; Madrid et al., 2010; Flores-Cervantes et al., 2011;Al-Harthi dan ElDeek, 2011; El-Deek et al., 2011;), fermentasi (Sujaya et al., 2011; Liu et al., 2012; Zhang et al., 2012; Uchida dan Miyoshi, 2013 dan Choi et al., 2014), ektraksi hidrokoloid (O'Doherty et al., 2010), pencucian dengan air tawar dan perlakuan kimia (Wisnu dan Rachmawati, 2005), suplementasi dengan starnox (starbio dan pignox) (Budiasa et al., 2008), perkaya dengan mikronutrien (Michalak et al., 2010), suplementasi minyak ikan sardine (Carillo et al., 2012). Metode pengolahan fermentasi rumput laut sebagai pakan ternak masih sedikit dan belum dilakukan pada rumput laut coklat. Metode pengolahan rumput laut secara kimia 
sudah dilakukan tetapi tidak diujikan pada ternak dan belum dilakukan untuk rumput laut coklat.

Pengolahan dengan tekanan uap panas adalah salah satu bentuk pengolahan secara fisika (Doyle et al., 1986). Pengolahan dengan tekanan uap cukup efektif dalam meningkatkan palatibilitas dan kecernaan bahan makanan (Broderick et al., 1993). Hal ini dimungkinkan karena dalam pengolahan pakan dengan tekanan uap dapat mengubah struktur kimia dan ikatan zat makanan dengan faktor pembatas (Sundstol, 1988)

Metode pemprosesan seperti autoklaf dan perebusan dapat meningkatkan kualitas bahan makanan seperti rumput laut dengan cara mempengaruhi serat dan ketersediaan zat nutrisi (Attia et al., 1998; El-Deek dan Brikaa, 2009; dan El-Deek et al., 2011). Mereka melaporkan bahwa pemprosesan meningkatkan nilai nutrisi dan performa ayam dibandingkan dengan produk mentah. Pengolahan dengan metode autoklaf menghasilkan nutrisi sehingga berpengaruh baik terhadap performa ternak (Yoshie et al., 1994; El-Deek and Al-Harthi, 2009; Al-Harthi et al., 2010; 2011).

Pengolahan rumput laut dengan metode fisika menggunakan tekanan uap panas telah dilaporkan oleh (Attia et al., 1998; El-Deek dan Al-Harthi, 2009; El-Deek dan Brikaa, 2009; Al-Harthi dan El-Deek, 2011; El-Deek et al., 2011; Al-Harthi dan El-Deek, 2012a; dan AlHarthi dan El-Deek, 2012a). Menurut Whyte et al. (1976) peningkatan suhu pengeringan terhadap rumput laut coklat Nereocystis luetkeana dan Macrocystis integrifolia dapat menurunkan kandungan alginat dan viskositasnya. Lebih lanjut dijelaskan olehnya bahwa rumput laut Nereocystis luetkeana yang dikeringkan pada suhu $80^{\circ} \mathrm{C}$ dan $105^{\circ} \mathrm{C}$ mengandung alginat berturut-turut $21.8 \%$ dan $13.8 \%$ dan viskositasnya berturut-turut 438 cps dan 403 cps. Hal yang sama juga dialami rumput laut Macrocystis integrifolia dengan kandungan alginat yang semula $21.6 \%$ menjadi $18 \%$ dan viskositasnya yang semula 1922 cps menjadi 972 cps. Selain itu,
Leo et al. (1990) mengatakan, Na-alginat yang disterilisasi dengan autoclave pada suhu $121^{\circ} \mathrm{C}$ selama 20 menit berpengaruh terhadap penurunan viskositas alginat. Hasil penelitian oleh Oates dan Ledward (1990) diketahui bahwa pengaruh pemberian panas pada suhu $140^{\circ} \mathrm{C}, 160^{\circ} \mathrm{C}$, dan $180^{\circ} \mathrm{C}$ selama 35 menit mengindikasikan kecepatan depolimerisasi alginat, alginat yang kaya mannuronat lebih cepat didegradasi dibandingkan dengan alginat yang kaya guluronat. Peneliti ini juga menyatakan bahwa mekanisme depolimersasi oleh panas pada alginat diduga menyerupai depolimerisasi polisakarida lainnya, termasuk pelepasan atom hidrogen dari ikatan.

Berdasarkan hasil penelitian sebelumnya mengenai pengolahan rumput laut dengan metode autoclave diketahui bahwa pemberian rumput laut coklat yang diberi perlakuan autoclave sebanyak $3 \%$ dalam ransum ayam petelur layak dijadikan sebagai campuran ransum unggas tanpa berdampak negatif terhadap performa ternak (Al-Harthy dan El-Deek, 2011). Lebih lanjut dijelaskan olehnya, suplementasi enzim dalam ransum ayam petelur yang mengandung $6 \%$ rumput laut coklat yang diolah dengan metode diautoklaf dapat meningkatkan produktivitas, performa dan kualitas kulit telur.

Sekarang ini, enzim digunakan untuk meningkatkan penggunaan bahan pakan dan meningkatkan performa ternak. Enzim-enzim ini meningkatkan kecernaan zat nutrisi, peningkatan penggunaan zat nutrisi dan menurunkan zat nutrisi yang tidak termanfaatkan serta mengurangi faktor antinutrisi (Attia and Abd El-Rahman, 2001; Attia et al., 2003; 2008; Madri et al., 2010; Flores-Cervantes et al., 2011).

\section{KESIMPULAN}

Rumput laut coklat (Phaeophyceae) memiliki potensi sebagai bahan pakan penyusun ransumayam petelur, tetapimemiliki faktor pembatas dalam penggunaannya, oleh karena itu dibutuhkan proses pengolahan 
sebagai upaya untuk meningkatkan ketersediaan zat nutrisi dan mendetoksifikasi senyawa antinutrisi.

\section{DAFTAR PUSTAKA}

Al-Harthi, M.A., A.A. El-Deek and Y.A. Attia. 2010. Utilization of dried whole eggs processed by different methods with or without growth promoting mixture on performance and lymphoid organs of broiler chicks. Int. J. Poultry Sci 9:511520.

Al-Harthi, M.A., A.A. El-Deek and Y.A. Attia. 2011. Impacts of dried whole eggs on productive performance, quality of fresh and stored eggs, reproductive organs and lipid metabolism of laying hens. Brit. Poultry Sci 52:333-344.

Al-Harthi. M.A. and A.A. El-Deek. 2011. The effects of preparing methods and enzyme supplementation on the utilization of brown marine algae(Sargassum dentifebium) meal in the diet of laying hens. Italian Journal of Animal Science 10(48): 195-203.

Al-Harthi. M.A. and A.A. El-Deek. 2012. Effect of different dietary concentrations of brown marine algae (Sargassum dentifebium) prepared by different methods on plasma and yolk lipid profiles, yolk total carotene and lutein plus zeaxanthin of laying hens. Italian Journal of Animal Science 11(64):347-353.

Al-Harthi. M.A. and A.A. El-Deek. 2012. Nutrient profiles of brown marine algae (Sargassum dentifebium) as affected by different processing methods for chickens. Journal of Food, Agriculture dan Environment 10 (1): 475-480.

Armin. F., S. Rahimi, A. M. Abkenar, Y. G. Ivari and H. Ebrahimi. 2015. Effect of sargassum sp. and vitamin e on stability of fish oil enriched meat in broiler chickens. Iranian Journal of Applied Animal Science 5(2): 385-392.
Astawan, M., T. Wresdiyati dan A.B. Hatanta. 2005. pemanfaatan rumput laut sebagai sumber serat pangan untuk menurunkan kolesterol darah tikus. Jurnal Hayati 12(1): 23-27.

Attia, Y.A. and S.A. Abd El-Rahman. 2001. Impact of multienzymes or Yea Sacc supplementation on growth performance and some carcass parameters of broiler chicks fed triticale containing-diets. Archiv Geflügelkd. 65:168-177.

Attia, Y.A., A.A. El-Deek and M. Osman. 1998. Evaluation of sunflower meal as feedstuff in diets of ducks. Archiv. für Geflügelk 62:273-282.

Attia, Y.A., E.M.A. Qota, F.A.M. Aggoor and A.K. Kies. 2003. Value of rice bran, its maximal utilization and upgrading by phytase and other enzymes and diet-formulation based on available amino acid for broiler chicks. Archiv Geflügelkd. 67:157-166.

Attia, Y.A., A.E. Tag El-Din, H.S. Zeweil, A.S. Hussein and M.A. Arafat. 2008. The effect of supplementation of enzyme on laying and reproductive performance in Japanese Quail hens fed nigella seed meal. J. Poultry Sci. 45:110-115.

Becker, W. 2004. Microalgae in human and animal nutrition. In: A. Richmond (ed.) Handbook of microalgal culture. Blackwell Publ., Oxford, UK pp. 312351.

Berger, 2006. Salt and trace minerals for livestock, poultry and other animals. Salt Institute Alexandria, Virginia.

Boyen, C., B. Kloareg, M. Polne-Fuller and A. Gibor. 1990. Preparation of alginate lyases from marine molluscs for protoplast isolation in brown algae. Phycologia. 29:173-181.

Broderick, G.A., J.H. Yang and R.G. Koegel. 1993. Effect of steam heating alfalfa hay on utilization by lactating dairy cows. J. Dairy Sci. 76:16

Brown, B.J. and J.F. Preston. 1991. L-Guluron 
alginate lyase from a marine bacterium associated with Sargassum. Carbohydr. Res. 211:91-102.

Brownlee, I.A., A. Allen, J.P. Pearson, P.W. Dettmar, M.E. Havler and M.R. Atherton. 2005. Alginate as a source of dietary fiber. Critical Reviews in Food Science and Nutrition. 45:497-510.

Budiasa, I.K.M., N.G.K. Roni and N.L.P. Sriyani. 2008. Pengaruh Pemberian Rumput Laut dalam Ransum Disuplementasi dengan Starnox terhadap Efisiensi Penggunaan Ransum Produksi dan Kualitas Telur pada Fase Peneluran Pertama Itik Bali. Laporan Penelitian Pusat Dokumentasi dan Informasi Ilmiah - Lembaga Ilmu Pengetahuan Indonesia PDII-LIPI.

Burtin, P. 2003. Nutritional value of seaweeds. EJEAFChe 2 (4).

Calnek, B.W., H.J . Barnes, C.W. Beard, L.R. Mc Dougald and J.M. Saif . 1997 . (Eds) . Diseases of Poultry . Tenth . Edition. Iowa State University Press. pp . 926-929.

Carrillo, S., E. López, M.M. Casas, E. Avila, R.M. Castillo, M.E. Carranco, C. Calvo and F. Pérez-Gil. 2008. Potential use of seaweeds in the laying hen ration to improve the quality of n-3 fatty acid enriched eggs. J Appl Phycol 20: 721728.

Carrillo, S., A. Bahena, M. Casas, M.E. Carranco, C.C. Calvo, E. Ávila and F. Pérez-Gi. 2012. The alga Sargassum spp. as alternative to reduce egg cholesterol content. Cuban Journal of Agricultural Science 46(2).

Casas, V.M. 2009. El alga marina Sargassum (Sargassaceae). En: Recursos marinos y servicios ambientales en el desarrollo regional. Eds. G.J. Urciaga, M.L.F. Beltrán \& B.D. Lluch. La Paz, Baja California, México. Pp. 139-156.

Charoen Pokphand. 2005. Malabsorption, Apa Saja Penyebabnya?. CP-BULLETIN Service. No. 2/ Tahun VI.
Choi. Y.J.S., R. Lee, and J.W. Oh. 2014. Effects of dietary fermented seaweed and seaweed fusiforme on growth performance, carcass parameters and immunoglobulin concentration in broiler chicks. Asian Australas. J. Anim. Sci. 27( 6) : 862-870.

Chojnacka, K., A. Saeid, Z. Witkowska and L. Tuhy. 2012. Active biologycal compound in brown seaweed. Open Conference Proceedings Journal. Hal : 20-28.

David, W. 2001. Overview of sea vegetable chemical composition. Available from: $\mathrm{http} / / \mathrm{www}$. surialink.com.

Direktorat Jenderal Perikanan Budidaya. 2013. Warta Ekspor: Rumput Laut Indonesia. Ditjen PEN/MJL/004/9/2013 September.

Doyle, P.T., C. Davendra and B.R. Pearce. 1986. Rice Straw as a Feed for Ruminant IDP, Camberra p. 54-70.

El-Deek, A.A., N.S. Isshak, S. Hamdy, N. Badawy and M.A. Asar. 1985. Performance of two strains of laying hens fed on practical diets containing levels of Seaweed during the rearing and laying stages. Egypt. Poultry Sci. J 5:1-11.

El-Deek, A.A. and M.A. Al-Harthi. 2009. Nutritive value of treated brown marine algae in pullet and laying diets. World Poultry Science Association,Proceedings of the 19th European Symposium on Quality of Poultry Meat, 13th European Symposium on the Quality of Eggs and Egg Products, Turku, Finland, 21-25 June 2009 pp. 1-12.

El-Deek, A.A. and M.A. Brikaa. 2009. Nutritional and biological evaluation of marine seaweed as a feedstuff and as a pellet binder in poultry diet. International Journal of Poultry Science 8(9): 875-881.

El-Deek, A.A. and M.A. Brikaa. 2009. Effect of different levels of seaweed in starter

Potensi, Faktor Pembatas, dan ... (Dewi et al.) 
and finisher diets in pellet and mash form on performance and carcass quality of ducks. International Journal of Poultry Science 8(10): 1014-1021.

El-Deek, A.A., M.A. Al-Harthi, A.A. Abdalla and M.M. Elbanoby. 2011. The use of brown algae meal in finisher broiler diets. Egypt. Poult. Sci 31(4): 767-781.

El-Deek, A.A., M.A. Al-Harthi and Y.A. Attia. 2011. Effect of different dietary levels of dried eggs by-product without or with shell on the performance of laying strain chicks from 2 to 8 week of age. Archiv. Für Geflügelk 75(1):20-29.

Flores-Cervantes, S., C.J. Casillas-Franco and J.R. Orozco-Hernández. 2011. Use of multienzimatic mix on sorghumsoybean meal based ration on hen performance. Ital. J. Anim. Sci. 10:e25.

Gammoned, M.A. and N. D'Orazio. 2015. Anti-obesity activity of the marine carotenoid fukosantin. Mr. Drug 13: 2196-2214.

Ghosh. S., D.L. Klass and D.P. Chynoweth. 1981. Biconversion of Macrocystis pyrifera to methane, J. Chem. Tech. Biotechnol 31:791-807.

Ginzberg, A., M. Cohen, U.A. Sod-Moriah, S. Shany, A. Rosenshtrauch, and S. Arad. 2000. Chickens fed with biomass of the red microalga Porphyridium sp. have reduced blood cholesterol level and modified fatty acid composition in egg yolk. Journal of Applied Phycology 12: 325-330.

Horhoruw, W.M., Wihandoyo dan T. Yuwanta. 2009. Pengaruh pemanfaatan rumput laut Gracilaria edulis dalam pakan terhadap kinerja ayam fase pullet. Buletin Peternakan 33(1): 8-16.

Horn, S.J. 2000. Bioenergy from Brown Seaweeds. Thesis. Department of Biotechnology Norwegian University of Science and Technology NTNU Trondheim, Norway.

Haugan, J.A., T. Aakemann, and S. Liaaen-
Jensen. 1995. Example 2: macroalgae and microalgae. In: Britton, G., LiaaenJensen, S., \& Pfander, H. (Eds.), Carotenoid. Volume 1A: Isolation and Analysis, pp. 215-226. Birkhauser Verlag, Basel, Switzerland.

Jacob, J. 2014. Including seaweed in organic poutry diets. Article.extension.org. University of Kentucky.

Jensen, A. 1963. The effect of seaweed carotenoids on egg yolk col-oration. Poult Sci 42:912 \pm 6 .

Jensen, A. 1996. Carotenoids of Norwegian Brown Seaweeds and of Seaweed Meals. Trondheim: Tapir 40 \pm 54 .

Julian, R.J. 1993. Ascites in poultry. Avian Pathol 22: 410-454.

Kementerian Kelautan dan Perikanan. 2011. Kelautan dan Perikanan dalam Angka 2011. Pusat Data Statistik dan Informasi.Http:///statistik.kkp.go.id (30 juni 2013).

Kiriyama, S., Y. Okasaki and A. Yoshida. 1968. Hypocholesterolemic effect of polysaccharides and polysaccharide foodstuffs in colesterol fed rats. J. Nutr. 97: 382 .

Kloareg, B. and R.S. Quatrano. 1988. Structure of cell walls of marine algae and ecophysiology functions of the matrix polysaccharides. Ocenogr. Mar. Biol. Ann. Rev. 26:259-315.

Koivikko, R. 2008. Brown algal phlorotannin improving ang applying chemical methods. Painosalama Oy, Finlandia.

Kumar, V.V. and P. Kaladharan. 2007. Amino acids in the seaweeds as an alternate source of protein for animal feed. Source of protein for animal feed J. Mar. Biol. Ass. India 49 (1) : $35-40$.

Lamela, M., J. Anca, R. Villar, J. Otero and J.M. Calleja. 1989. Hypoglycemic activity of several seaweed extract. J. Ethnopharmacol. 27: 35.

Larsen, B., K. Hoøen and K. Østgaard. 1993. Kinetics and specificity of alginate 
lyases. Hydrobiologia 260/261:557561.

Leo, W.J., J. Aiden, McLoughlin and D.M. Malone. 1990. Effects of sterilization treatments on some properties of alginate solutions and gels. Biotechnol. Prog. 1990, 6, 51-53

Linsley, R.K., M.A. Kohler, J.L.H. Paulhus and Y. Hermawan, 1996. Hidrologi untuk Insinyur (Hydrology for insinyur). Erlangga, Jakarta.

Liu, X.H., S.P. Zhang, L. Han and Y. Li. 2012. Influence of several fermentation on seaweed waste of feed. Journal of Sustainable Bioenergy Systems. 2: 108-111.

Madrid, J., P. Catalá-Gregori, V. Garcia and F. Hernández. 2010. Effect of a multienzyme complex in wheatsoybean meal diet on digestibility of broiler chickens under different rearing conditions. Ital. J. Anim. Sci. 9:e1.

Mahata, M.E., Y.L. Dewi, M.O. Sativa, S. Riski, Hendro, Zulhaqqi, dan A. Zahara. 2015. Potensi rumput laut coklat dari Pantai Sungai Nipah sebagai pakan ternak. Penelitian Mandiri Fakultas Peternakan Universitas Andalas.

Madhusudan, C., S. Manoj, K. Rahul and C. M. Rishi. 2011. Seaweeds: A diet with nutritional, medicinal and industrial value. Research Journal of Medicinal Plant 5:153-157. (Available online at: http://dx.doi.org/10.3923/ rjmp.2011.153.157) (verified 6 Jan 2014)

Matsuno, T. 2001. Aquatic animal carotenoids. Fisheries Science 67: 771-783.

Meliandasari, D., L.D. Mahfudz dan W. Sarengat. 2013. Pengaruh penggunaan tepung rumput laut (Gracilaria verrucosa) dalam ransum terhadap perlemakan ayam broiler umur 42 hari. Animal Agriculture Journal 2(1): 120 127.

Michalak, I., K. Chojnacka, Z. Dobrzanski,
H. Gorecki, A. Zielinska, M. Korczynski and S. Opalinski. 2010. Effect of macroalgae enriched with microelements on egg quality parameters and mineral content of eggs, eggshell, blood, feathers and droppings. Journal of Animal Physiology and Animal Nutrition 95: 374-387.

Mishra, V.K., F. Temelli, P.F. Ooraikul Shacklock and J.S. Craigie. 1993. Lipids of the red alga Palmaria palmata. Botanica Marina, 36(2): 169174.

Moen, E., B. Larsen, K. Østgaard and A. Jensen. 1999. Alginate stability during high salt preservation of Aschophyllum nodosum. J. appl. Phycol 11:21-25.

Mohd, H., C.C. Yen and C.Y. Ching .2000. Nutritional composition of edible seaweed Gracilaria changgi. Food Chem 68:69-76.

Morand, P., B. Carpentier, R.H. Charlier, J. Mazé, M. Orlandini, B.A. Plunkett and J. de Wart .1991. Bioconversion of seaweeds. In Guiry MD, Blunden G (eds) Seaweed Resources of Europe: Uses and Potential. John Wiley \& Sons, Chichester 95-148.

Mouritsen, O.G. 2009. Tang-grøntsager fra havet. Nyt Nordisk Forlag, Arnold Busck, Copenhagen, 284 pp (in Danish)

Naidu'., K.A., A. Tewari, H.V. Joshi, S. Viswanath', H.P. Rameshi and S.V. Rao. 1993. Evaluation of nutritional quality and food safety of seaweeds of india. Journal of Food Safety 13: 77-90

Nomura, T., M. Kikuch, A. Kubodera and Y. Kawakami. 1997. Proton-donative antioxidant activity of fucoxanthin with 1,1-diphenyl-2-picrylhydrazyl (DPPH). Biochem Mol Biol Int. 42(2): 361-70.

Norziah, M.H. and C.Y. Ching. 2000. Nutritional composition of edible seaweed Gracilaria changgi- an edible species of nori from Nova Scotia. Food Chemistry, 68: 69-76

Potensi, Faktor Pembatas, dan ... (Dewi et al.) 
Nursid, M., T. Wikanta dan R. Susilowati. 2013. Aktivitas Antioksidan, Sitotoksisitas Dan Kandungan Fukosantin Ekstrak Rumput Laut Coklat dari Pantai Binuangeun, Banten. JPB Kelautan dan Perikanan. 8(1):73-83.

Oates, C. G. and D. A. Ledward. 1990. Studies on the effect of heat on alginates. Food Hydrocolloids 4(3): 215-220.

O’Doherty. J.V., S. Dillon, S. Figat, J.J. Callan and T. Sweeney. 2010. The effects of lactose inclusion and seaweed extract derived from Laminaria spp. on performance, digestibility of diet components and microbial populations in newly weaned pigs. Animal Feed Science and Technology. Animal Feed Science and Technology 157:173-180.

Okuzumi, J., T. Takahashi, T. Yamane, Y. Kita, M. lnagake, K. Ohya, H. Nishino and Y. Tanaka. 1993. Inhibitory effects of fucoxanthin, a natural carotenoid, on N-ethyl-N'-nitro-Nnitrosoguanidine induced mouse duodenal carcinogenesis. Cancer Letters, 68:159- 168 Elsevier Scientific Publishers Ireland Ltd.

Ozaki, H., M. Kawahara, R. Nogami, Y. Yamada and H. Takahash. 2013. Supplemental red alga, Gracilaria vermiculophylla, from a Brackish Japanese Lake, strengthens egg shells and improves the haugh unit of eggs in laying hens. J Fisheries Livest Prod, 2: 2-5.

Pal, A., M.C. Kamthania and A. Kumar. 2014. Bioactive Compounds and Properties of Seaweeds- A Review. Open Access Library Journal, 1: e752. http://dx.doi. org/10.4236/oalib.1100752.

Panlasigui, L.N., O.Q. Baello, J.M. Dimatangal and B.D Dumelod. 2003.

Blood cholesterol and lipid-lowering effects of carrageenan on human volunteers. Asia-Pacific J. Clin. Nutr. 12: 209

Rachmaniar, R. 2005. Penelitian
Kandungan Kimia Makroalgae untuk Neutroceuticals dan Agrochemicals. Laporan Akhir P2O LIPI. Jakarta : 22 hal.

Rasyid, A. 2004. Pemanfaatan alga. Oseana 29 (3): 9-15.

Ren, D., H. Noda, H. Amano, T. Nishino and Nishizana. 1994. Study on and Hypertensive and Anthiperlipidemic Effect of Marine Algae. Fish Sci. 60: 83-88.

Rimber, I.I. 2007. Why seawees. Degree Diss., Sam Ratulangi University, Manado, Indonesia.

Santosa, G.W. 2003. Budidaya Rumput Laut. Program Community College Industri Kelautan dan Perikanan. Universitas Diponegoro. Semarang.

Schiavone, A., R. Chiarini, M. Marzoni, A. Castillo, S. Tassone and I. Romboli. 2007. Breast meat traits of Muscovy ducks fed diet on a microalgae Crypthecodinium cohnii meal supplemented.. Brit. Poultry Sci. 48:573-579.

Schiedt, K. 1985. Animal Nutrition Events. In: Hoffmann-LaRoche AG, Report No 2186.

Song, M.Y., S.K. Ku and J.S. Han. 2012. Genotoxicity testing of low molecular weight fucoidan from brown seaweeds. Food Chem. Toxicol. 50: 790-796.

Strand, A., O. Herstad and S. LiaaenJensen1998. Fucoxanthin metabolites in egg yolks of laying hens. Comparative Biochemistry and Physiology Part A 119: $963 \pm 974$.

Sudariastuty, E. 2011. Materi Penyuluhan Perikanan: Pengolahan Rumput Laut. PPKP. Jakarta.

Sujaya, I.N., N.K. Sutiari, N.W. Arya Utami, dan K.A. Nocianitri. 2011. Fermentasi Rumput Laut secara In Vivo oleh Bakteri Saluran Pencernaan Mencit. The Excellence Research Universitas Udayana. 
Sundstol, F. 1988. Feedstuffs. 5. Straw and other fibrous by-products. Livest. Prod. Sci., 19: 137-158.

Surono, A. 2004. Profil Rumput Laut Indonesia. Direktorat Jenderal Perikanan Budidaya. Departemen Kelautan dan Perikanan. Jakarta.

Suzuki. T., K. Nakal, Y. Yosie, T. Shiral and T. Hirano. 1993. Effect of Sodium Alginates Rich in Guluronic and Mannuronic Acids on Cholesterol Levels and Digestive Organs on HightCholesterol-Fed Rats. Nippon Suisan Gakkaishi 59:545-551.

Synytsya, A., W.J. Kim and S.M. Kim. 2010. Structure and antitumor activity of fucoidan isolated from sporophyll of Korean brown seaweed Undaria pinnatifida. Carbohydr. Polym 81: 4148.

Tabbu, R.C. 2002. Penyakit Ayam dan Penanggulangannya. Volume 2. Penerbit Kanisius, Yogyakarta. hlm. 305-320.

Tri, A.B. 1993 . Manual Kesehatan Unggas. Penerbit Kanisius, Yogyakarta. hlm. 179-180.

Tyczkowski, J.K. and P.B. Hamilton. 1986a. Lutein as a model dihydroxycarotenoid for the study of pigmentation in chickens. Poult Sci. 65:1141 \pm 5 .

Tyczkowski, J.K. and P.B. Hamilton. 1986b. Absorption, transport, and deposition in chickens of lutein diester, a carotenoid extracted from marigold (Tagetes erecta) petals. Poult Sci. 65:1526 \pm 31 .

Uchida, M. and T. Miyoshi. 2013. Fermentation of seaweeds-alchemy of algae and aquatic plant biomass. J Food Process. 4:10.

Urikura, I., Sugawara, T. and Hirata, W. 2011. Protective effect of fucoxanthin against UVB-induced skin photoaging in hairless mice. Biosci. Biotechnol. Biochem 75(4): 757-760.

Ventura,. M.R, J.I.R. Castafion and J.M.
McNab. 1994. Nutritional value of seaweed ( Ulva rigida) for Poultry. Animal Feed Science and Technology 49: 87-92.

Wawa, J.E. 2005. Pemerintah provinsi harus segera menyiapkan lahan pembibitan di dalam Suparmi dan Achmat. S. 2009. Mengenal potensi rumput laut : kajian pemanfaatan sumber daya rumput laut dari aspek industri dan kesehatan. Sultan Agung Vol Xliv No. 118.

Wehr, J.D. 2003. Brown Seaweed. In : Wehr, J.D., \& Sheath, R.G. Freshwater Algae of North America. Academic Press, San Diego. p. 757-773.

Whyte, J.N.C., J.R. Englar and M. Kung. 1976. Alginate Degradation in.situ Accompanying Thermal Drying of the Marine Algae Nereocyctis luetkena and Macrocystis integrifolia. Technical Report No. 643. Dept. of Environment Fisheries and Marine Service.

Welch, V.A. and J.T. Borlak. 2008. Absorption and transport of dietary lipid. In: Fatty acids in foods and their health implications. Ed. C.K. Chow. CRC Press. Boca Raton, Florida, USA. Pp. 562-589

Widiastuti, B.L. 2001. Efek Pemberian Komponen Serat Pangan dari Rumput Laut Terhadap Profil Kolesterol Darah, Mikroflora Usu dan Histologi Usus Tikus Percobaan. Tesis. Program Pascasarjana IPB. Bogor.

Wikanta, T. Khaeroni dan L. Rahayu. 2002. Pengaruh pemberian natrium alginate terhadap penurunan kadar glukosa darah tikus. Jurnal Penelitian Perikanan Indonesia 8(6). . 2003. Pengaruh pemberian natrium alginat terhadap penurunan kadar kolesterol total darah dan bobot badan tikus. Jurnal Penelitian Perikanan Indonesia 9(5).

Winarno. 1996. Teknologi Pengolahan Rumput Laut. Pustaka Sinar Harapan. Jakarta. 107 Hlm. 
Wisnu, R. dan D. Rachmawati. 2005. Analisa Komposisi Nutrisi Rumput Laut (Euchema cotoni) di Pulau Karimunjawa dengan Proses Pengeringan Berbeda. Laporan Kegiatan, Fakultas Prikanan dan Ilmu Kelautan Universitas Diponegoro.

Wang, H.W., Y.Q. Liu and Y.H. Wang. 2011. Optimization of ultrasonic-assisted extraction of total flavonoids from leaves of the Artocarpus heterophyllus by Response Surface Methodology, Zhong Yao Cai 34(7):1125-9.

Whyte, J.N.C., J.R. Englar and M. Kung. 1976. Alginate Degradation in.situ Accompanying Thermal Drying of the Marine Algae Nereocyctis luetkena and Macrocystis integrifolia. Technical Report No. 643. Dept. of Environment Fisheries and Marine Service.

Wong, K.H., S.W. Sam, P.C.K. Cheung and Ang PO Jr. 1999. Changes in Lipid Profiles of Rats Fed with SeaweedBased Diet. Nutrition Research 19(10): 1519-1527.

Yan, X., Y. Chuda, M. Suzuki and T. Nagata. 1999. Fucoxanthin as the major antioxidant in Hijikia fusiformis, a common edible seaweed. Biosciencen Biotechnology and Biochemistry 63(3):
605-607.

Yoshiko, S. and N. Hoyoko. 2007. Fucoxanthin, a natural carotenoid, induces G1 arrest and GADD45 gene expression in human cancer cells. In Vivo 21(2): 305-309.

Yoshie, Y., T. Suzuki, T. Shirai and T. Hirano. 1994. Changes in the contents of dietary fibers, minerals, free amino acids, and fatty acids during processing of dry Nori. Nippon Suisan Gakk 60:117-123.

Yuan, Y. 2008. Marine algal constituens. In: Marine nutraceuticals and functional foods. Eds. C. Barrow and F. Shahidi. CRC Press. Boca Raton, Florida, USA. p. 259

Zahid, P.B., K. Aisha and A. Ali. 1995. Green seaweed as component of poutry feed. Bangladesh. J. Bot 24(21): 153-156.

Zhang, S., Xiaojian Hu, Jie Ma, Zhengqiang Ma, Xiaohui Liu, Lei Cui. 2012. Study on feed fermented from seaweed waste. African Journal of Microbiology Research 6(50): 7610-7615.

Zaid, P.B., A. Ali and M.e-Jabeen Zahid. 2001. Brown seaweed as supplement for broiler feed. Hamdard Medicus 44(2): 98-101. 